\title{
炭素繊維強化熱可塑性樹脂の繊維樹脂界面せん断強度に及ぼす
} 炭素䋊維の空気酸化の影響十

\author{
田中 和人* 奥田 沙也** 片山 傳生*

\section{Effect of Air Oxidation of Carbon Fiber on Interfacial Shear Strength of Carbon Fiber Reinforced Thermoplastics}

by

\author{
Kazuto TAnAKA*, Saya OKudA** and Tsutao Katayama*
}

\begin{abstract}
Carbon fiber reinforced thermoplastics (CFRTPs) are expected to be used for the structural parts of automobiles due to their properties, such as high recyclability and ability of secondary process. They are studied for the purpose of improving productivity and reducing costs. Among thermoplastics, PA6 and PP are expected to be used. PA6 is relatively good in adhesion to carbon fiber among thermoplastics, whereas PP is inferior in adhesion to carbon fiber because it has no polarity. As a fiber modification method for improving the fiber matrix interfacial shear strength (IFSS), oxidizing of carbon fiber has developed. In this study, single fiber pull-out tests of CF/PA6 and $\mathrm{CF} / \mathrm{PP}$ were conducted to clarify the effect of air oxidation of carbon fiber on the IFSS. The effect of temperature on PA6 and the temperature holding time at specimen preparation for PP on the IFSS were also clarified. The IFSS of CF/PA6 was improved by oxidizing carbon fiber, and the IFSS of CF/PP was improved by oxidizing carbon fiber and using PP with MAPP for matrix. For PA6, the test specimen that was prepared at the higher temperature has higher IFSS. For PP, the test specimen that was prepared with longer temperature holding time has higher IFSS.
\end{abstract}

\section{Key words}

Carbon fiber reinforced thermoplastics, Carbon fiber, Air oxidation, Maleic anhydride grafted polypropylene, Single fiber pull-out test, Interfacial shear strength

\section{1 緒言}

繊維強化樹脂複合材料において繊維樹脂界面は, 母材 から強化繊維への応力の伝達において重要な役割を果 たす，そのため，複合材料の機械的特性は強化繊維と樹 脂の特性だけではなく, 繊維樹脂界面特性にも大きく影 響を受ける ${ }^{1)}$, 2)ので, 繊維樹脂界面接着性の制御が必要 である。

熱可塑性樹脂を母材に用いた炭素繊維強化熱可塑性 樹脂複合材料 (Carbon Fiber Reinforced Thermoplastic: CFRTP） はリサイクル性が高く, 部材の二次加工が可能 であるといった優れた特性から，量産自動車への利用が 期待されており，生産性の向上や低コス卜化を目的とし て, 研究開発が進められている3 ${ }^{3)} 7$ ).

量産自動車などの大量生産品のマトリックスとしては, 熱可塑性樹脂の中でも，PA6 や PP の利用が期待されてい る ${ }^{3)}$. PA6 は熱可塑性樹脂の中では比較的炭素瀻維との接 着性に優れているのに対して，PP は極性を持たないため 炭素繊維との接着性に劣る ${ }^{8}$. 絨維樹脂界面せん断強度を 向上させるための樹脂の改質方法として, PP にマレイン 酸変性ポリプロピレン（Maleic anhydride grafted polypropylene: MAPP) を添加する方法がある. $\mathrm{COOH}$ 基
を持つMAPP をPP に添加すると繊維樹脂界面接着性が向

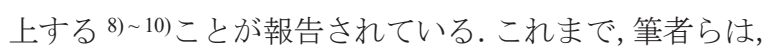
炭素繊維と MAPP 添加 PP の繊維樹脂界面において, 高温 保持により繊維樹脂界面せん断強度が高くなる ${ }^{11)}$ こを 報告しており, これは, 纎維と樹脂の界面での化学結合 の増加が原因と考えられ, 温度や時間が纎維樹脂界面せ 儿断強度に与える影響を明らかにすることが重要である。 一方, 炭素繊維の改質方法としては, 表面を酸化させ る手法がある。陽極酸化や空気酸化により炭素繊維表面 に $\mathrm{COOH}$ 基や $\mathrm{OH}$ 基を生成 ${ }^{1)}$, 12) させると, 熱硬化性樹脂 であるエポキシ樹脂との纎維樹脂界面せん断強度が向 上する ${ }^{1)} 13$ ことが報告されている。これまで, 炭素繊維 のオゾン酸化により, PA6をマトリックスとした複合材 料の曲げ強度や引張強度, 炭素繊維と PA6 の界面接着性 が向上寸る ${ }^{14)}$ こ, 炭素瀻維表面に酸素含有官能基が生 成され繊維樹脂界面せん断強度が向上寸る ${ }^{15}$ ことが報 告されている. 湿式プロセスである陽極酸化は酸化処理 後に, 後処理洗浄および乾燥を必要とし ${ }^{13)}$, 乾式酸化の 一種であるオゾン酸化は処理後に残存オゾンの分解を 行う必要があるため, 炭素繊維の酸化には, 乾式プロセ スの中でも後処理が不必要な空気酸化が適していると

$\dagger$ 原稿受理 令和元年11月18日 Received Nov. 18, 2019 @2020 The Society of Materials Science, Japan

* 正 会 員 同志社大学生命医科学部医工学科 ₹610-0394 京都府京田辺市多々羅都谷 Dept. of Biomed. Eng., Doshisha Univ., Tatara-miyakodani, Kyotanabe, 610-0394.

** 同志社大学大学院 ₹ 610-0394 京都府京田辺市多々羅都谷

Dept. of Biomed. Eng., Doshisha Univ., Tatara-miyakodani, Kyotanabe, 610-0394. 
考えられる

そこで本研究では, 空気酸化を施した炭素繊維と, PA6 あるいはPP と MAPP 添加 PP をマトリックスに用いて単 繊維引抜き試験を行い，繊維樹脂界面せん断強度に及ぼ す炭素繊維の空気酸化の影響を明らかにした。また，PA6 については温度が，MAPP 添加 PP については試験片作製 時の温度保持時間が繊維樹脂界面せん断強度に及ぼす影 響も明らかにした。

\section{2 供試材および実験方法}

\section{$2 \cdot 1$ 供試材}

炭素繊維には PAN 系炭素繊維開䋊糸（24K，日本特殊 織物）を用いた。 未処理の炭素繊維を As-received-CF と称 することとする。炭素繊維の表面は走査型電子顕微鏡

(Scanning Electron Microscope: SEM，JST-6390LT，日本電 子）および電界放出型走査電子顕微鏡（Field-Emission Scanning Electron Microscope: FE-SEM, SU-8020, 日立八 イテクノロジーズ）を用いて観察を行った.

単繊維引抜き試験片の母材として用いる樹脂には, PA6 （1015B，宇部興産，融点 $226.5^{\circ} \mathrm{C}$, Fig. 1)，PP（MA3， 日本ポリプロ，融点 $172.7^{\circ} \mathrm{C}$, Fig. 2), MAPP (ユーメッ クス 1001 ，三洋化成，融点 $142{ }^{\circ} \mathrm{C}$, Fig. 3）を用いた. MAPP 添加 PP は，PP およびMAPP を粉砕し，PP に対し て $4 \mathrm{wt} \%$ の MAPP を添加し, 卓上二軸スクリューエクス トルーダー（Process11，Thermo Fisher Scientific）を用い て作製した．PP および MAPP 添加 PP については，乾式 自動密度計（アキュピック 1330，島津製作所）を用いて 密度を測定した。

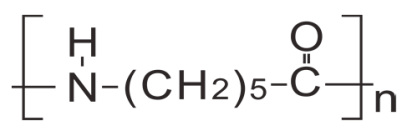

Fig. 1 Constitutional formula for PA6.

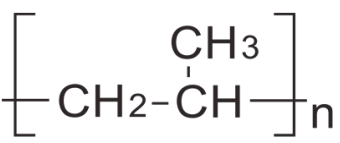

Fig. 2 Constitutional formula for PP.

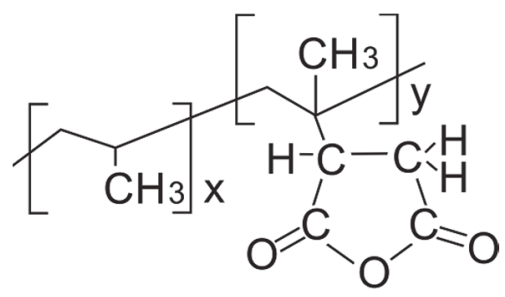

Fig. 3 Constitutional formula for MAPP.

\section{$2 \cdot 2$ 炭素繊維表面の改質}

市販の炭素繊維はエポキシ樹脂をマトリックスに利用 することを想定したサイジング処理が施されていると考 えられる.これらは, 熱可塑樹脂との相性が悪い16)ため, Fig. 4 に概略図を示す化学気相蒸着装置（CVD, MPCVD-70，マイクロフェーズ）を用いて，Ar 環境下で $350{ }^{\circ} \mathrm{C}$ で $20 \mathrm{~min}$ 保持し，サイジング剤を除去した。 サイ ジング剤を除去した炭素繊維を Unsized-CF と称すること とする。炭素繊維の表面観察には, FE-SEM を用いた。

Unsized-CF は, 前述のCVD装置を用いて, 温度を $300^{\circ} \mathrm{C}$, 保持時間を $180 \mathrm{~min}$ として，空気中で表面を酸化させた. サイジング剤除去後に空気酸化処理を施した炭素繊維を O-Unsized-CF と称することとする，炭素繊維表面に対し $\tau \mathrm{X}$ 線光電子分光装置（ESCA，KRATOS ULTRA2，島津 製作所）を用いて，300 $\mu \mathrm{m} \times 700 \mu \mathrm{m}$ の範囲に対して元素 分析を行い, 表面の官能基を分析した.

\section{$2 \cdot 3$ 単繊維引抜き試験}

繊維樹脂界面せん断強度は，単繊維引抜き試験により 評価した. 単繊維引抜き試験片作製の概略図を Fig. 5 に示 す. As-received-CF, Unsized-CF および O-Unsized-CF に対 して, 䋊維束から取り出した単繊維一本をポリエステル 製のタブに接着し，ホットプレート上で PA6 については

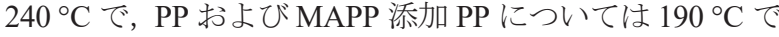
溶融させた樹脂に繊維の先端を挿入した後, 空冷するこ とで試験片を作成した。それぞれの組み合わせの試験片 の名称を Table 1 に示す.

また，O-Unsized-CF/(PP+MAPP)に対しては，試験片作 成時の温度保持時間が界面せん断強度に及ぼす影響を明 らかにするため， $190{ }^{\circ} \mathrm{C} て ゙ 1 ， 2 ， 3 \mathrm{~min}$ 間保持した試験片

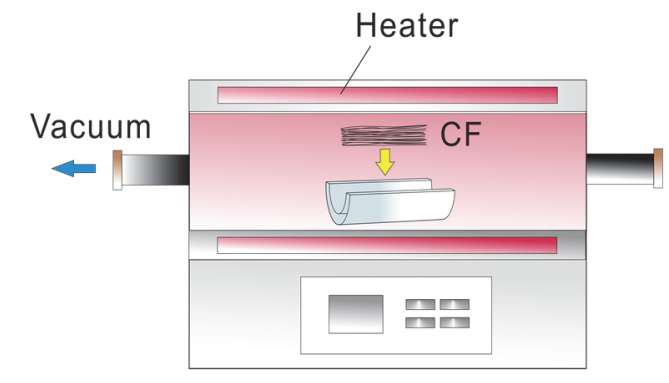

Fig. 4 Schematic drawing of CVD method.

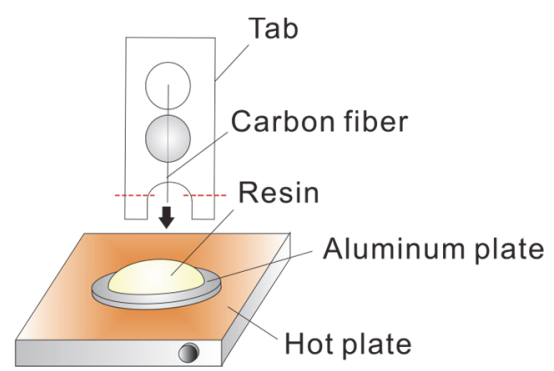

Fig. 5 Schematic drawing of fabrication of a pull-out specimen. 
Table 1 Names of test specimens.

\begin{tabular}{r|c|c|c|c}
\hline \multirow{2}{*}{\multicolumn{2}{c|}{ Specimen }} & \multicolumn{3}{c}{ Matrix } \\
\cline { 3 - 5 } & PA6 & PP & PP with MAPP \\
\hline \multirow{3}{*}{$\begin{array}{c}\text { Carbon } \\
\text { Fiber }\end{array}$} & As-received-CF & As-received-CF/PA6 & As-received-CF/PP & \\
\cline { 2 - 5 } & Unsized-CF & Unsized-CF/PA6 & Unsized-CF/PP & Unsized-CF/(PP+MAPP) \\
\cline { 2 - 5 } & O-Unsized-CF & O-Unsized-CF/PA6 & O-Unsized-CF/PP & O-Unsized-CF/(PP+MAPP) \\
\hline
\end{tabular}

も準備した。これらを，それぞれ O-Unsized-CF/ (PP+MAPP) $1 \mathrm{~m} \quad, \quad \mathrm{O}-$ Unsized-CF/(PP+MAPP) $2 \mathrm{~m} \quad$ ， O-Unsized-CF/(PP+MAPP) $3 \mathrm{~m}$ と称することとする.さらに, O-Unsized-CF/PA6 に対しては，試験片作製時の温度が界 面せん断強度に及ぼす影響を明らかにするため, $230{ }^{\circ} \mathrm{C}$ で作製した試験片も準備した。この試験片を O-Unsized-CF/PA6(230)と称することとする.

単繊維引抜き試験には微小材料用引張試験機（マイク ロサーボ MMT-11N，ロードセル $2.5 \mathrm{~N}$ ，島津製作所）を 用い, 変位速度は $1.67 \times 10-6 \mathrm{~m} / \mathrm{s}$ とした. 試験直前に, Fig. 5 中の試験片を支えているタブの点線部分を切断し, 繊維 のみに荷重がかかるようにして引き抜き試験を実施し， 試験中の最大荷重 Pmax を算出した. 引抜き試験後のす心゙ ての纎維は Fig. 6 に示すように, SEM により観察し, 埋 込先端からメニスカス部分までの長さである埋込長さ $l$ と, 繊維の直径 $d$ を測定し, 繊維樹脂界面せん断強度 $\tau$ は式（1）より算出した.

$$
\tau=\frac{P_{\max }}{\pi d l}
$$

\section{3 実験結果および考察}

\section{$3 \cdot 1$ 密度測定結果}

PP と MAPP 添加 PP の密度測定結果を Fig. 7 に示す. それぞれの密度の值に有意差はなかった. 筆者らは CF/PA において，樹脂の密度が高いほど，樹脂が炭素繊維を繊 維の半径方向に締め付ける力が強くなり，䋊維樹脂界面

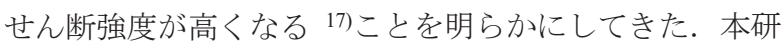
究において PP と MAPP 添加 PP の密度の值に有意差がな かったことより，樹脂が炭素繊維を締め付ける力に差は 無いと考えられる.

\section{$3 \cdot 2$ 炭素繊維表面分析結果}

As-received-CF，Unsized-CF の FE-SEM による観察結果 を Fig. 8 に示す. Unsized-CF では炭素繊維表面の繊維軸方 向に筋状の微細な凹凸が全体に観察できるのに対し， As-received-CF では凹凸が鮮明でない部位も観察できた。

$\mathrm{ESCA}$ の分析結果から波形分離により求めた $\mathrm{C} 1 \mathrm{~s}$ 結合 コンポーネント比率を Table 2 に示す. サイジング剤が塗 布されていると考えられる As-received-CF にはグラファ イトが存在しないのに対し, Unsized-CF では多数検出さ れており, サイジング剤が熱処理によって除去されたと 考えられる. ESCA による試料の検出深さは数 $\mathrm{nm}$ 程度で あることから, Fig. 8 の SEM 画像で微細な凸凹が観察出

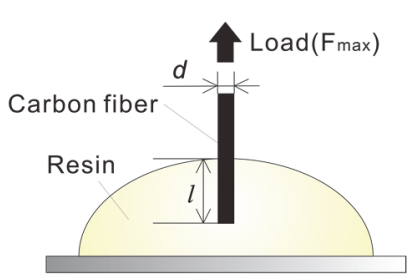

(a) Schematic drawing of a pull-out test specimen

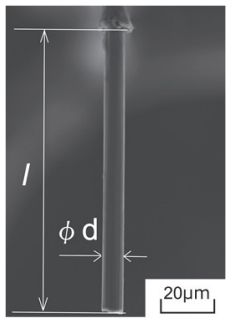

(b) SEM observation of a pulled-out carbon fiber
Fig. 6 Embedded fiber length and fiber diameter.

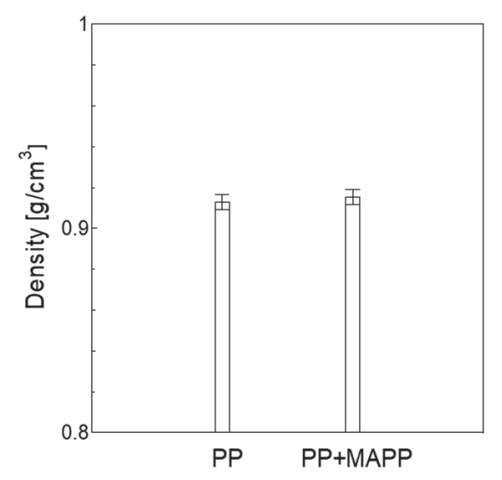

Fig. 7 Density for resin.

$(\mathrm{N}=5$, mean \pm S. D. $)$

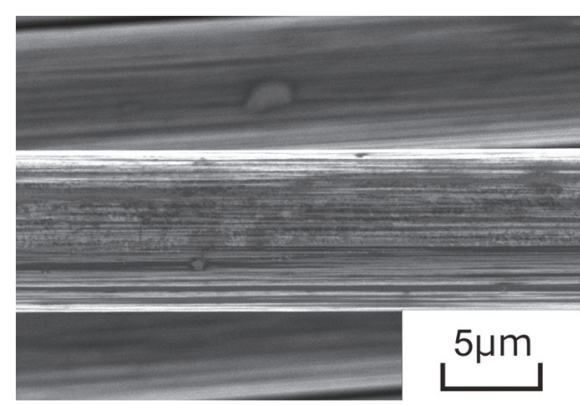

(a) As-received-CF

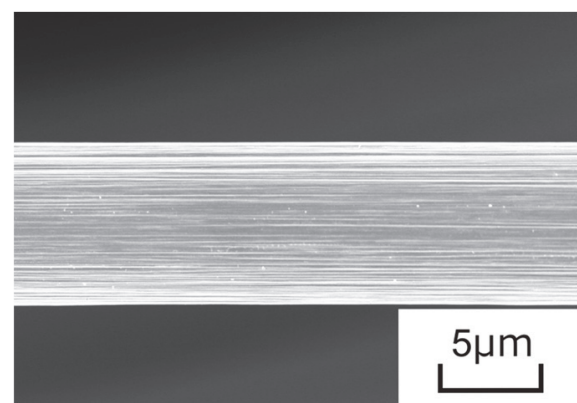

(b) Unsized-CF

Fig. 8 SEM images of carbon fibers. 
Table 2 Functional group analysis of carbon fiber surface.

\begin{tabular}{c|c|c|c|c|c|c|c}
\hline & \multicolumn{7}{c}{ Component Ratio (\%) } \\
\cline { 2 - 9 } & Graphite & C-C & C-O & C=O & COO & COONH & Shake-up \\
\hline As-received-CF & 0.0 & 47.1 & 50.7 & 0.0 & 0.0 & 1.6 & 0.6 \\
\hline Unsized-CF & 67.5 & 16.1 & 8.1 & 3.9 & 1.2 & 1.9 & 1.2 \\
\hline O-Unsized-CF & 66.4 & 13.8 & 9.6 & 4.8 & 1.7 & 2.4 & 1.4 \\
\hline
\end{tabular}

来ている部位にもサイジング剂は炭素繊維を薄く覆うよ うに付着しており，凹凸が鮮明でない部位には多量にサ イジング剽が付着していると考えられる。

Table 2 に示したように, O-Unsized-CF は Unsized-CF よ りも $\mathrm{C}-\mathrm{C}$ の比率が低く, $\mathrm{CO}, \mathrm{COO}$ および $\mathrm{C}=\mathrm{O}$ の比率は 高い值を示した．炭素繊維は酸化すると表面の黒鉛結晶 端部もしくは非晶質炭素に $\mathrm{COOH}$ 基や $\mathrm{OH}$ 基 ${ }^{1)}, \mathrm{C}=\mathrm{O}$ が 生成する ${ }^{18)}$ ことが報告されている。したがって酸化炭素 繊維の表面は Fig. 9 に示すように酸素含有官能基が生成 されると考えられる，本研究において，炭素繊維の空気 酸化により生成された $\mathrm{COOH}$ 基や $\mathrm{OH}$ 基のために, $\mathrm{CO}$ および $\mathrm{COO}$ の比率が増加し, $\mathrm{C}=\mathrm{O}$ の比率も増加したと考 えられる。

\section{$3 \cdot 3$ 単繊維引抜き試験}

単繊維引抜き試験により求めた $\mathrm{CF} / \mathrm{PA} 6$ の繊維樹脂界 面せん断強度を Fig. 10 に示す.サイジング剂を除去した Unsized-CF/PA6 は As-received-CF/PA6 よりも高い繊維樹 脂界面せん断強度を示した。筆者等はこれまで，サイジ ング剂を除去することで炭素繊維とPA6 との界面せん 断強度が向上寸る ${ }^{16}$ ことを報告しており，同様の結果が 得られた. $3 ・ 2$ 節で述べたように, ESCAによる分析結 果では As-received-CF には存在しない $\mathrm{C}=\mathrm{O}$ および $\mathrm{COO}$ が Unsized-CF では検出されていた. PA 樹脂と $\mathrm{COOH}$ 基 は水素結合する ${ }^{19)}$ と考えられ，Fig. 11 のように，PA6の $\mathrm{CO}$ や NH とサイジング剤除去によって炭素繊維表面に 現れた酸素含有官能基との水素結合が促進されたため, Unsized-CF では, 繊維樹脂界面せん断強度が高い值を示 したと考えられる。

O-Unsized-CF/PA6 は Unsized-CF/PA6 より高い繊維樹 脂界面せん断強度を示した。 引抜き試験後の繊維表面の メニスカス付近の FE-SEM 観察結果を Fig. 12 に示寸. Unsized-CF/PA6 では，単繊維引き抜き試験片を作製する 前の瀻維表面に観察できる Fig. 8 亿示したような繊維軸 方向の筋状模様が露出していた. O-Unsized-CF の纎維表 面は, 観察結果は省略するものの Unsized-CF と同様に緎 維軸方向の筋状模様が観察された。一方, O-Unsized-CF/PA6 には Fig. 12(b)中に矢印で示寸部分に 繊維軸方向の筋状模様が一部見えている部分もあるも のの，樹脂が全体的に繊維を覆っていた. $3 \cdot 2$ 節で述心゙ たように, O-Unsized-CF の $\mathrm{C}=\mathrm{O}$ および $\mathrm{COO}$ の比率が Unsized-CFよりも高く, 空気酸化により多くの酸素含有 官能基が生成された。そのため, O-Unsized-CF/PA6 は

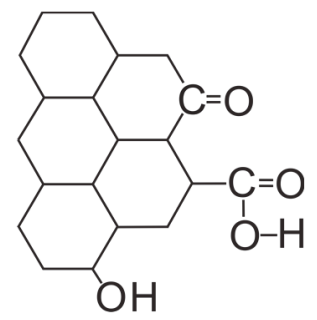

Fig. 9 Constitutional formula for oxidized carbon fiber.

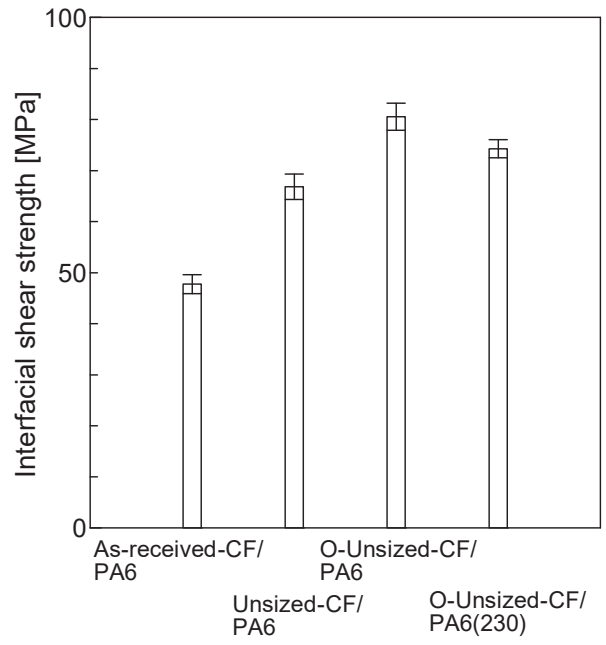

Fig. 10 Interfacial shear strength for CF/PA6.

$(\mathrm{N}=5$, mean \pm S. D. $)$

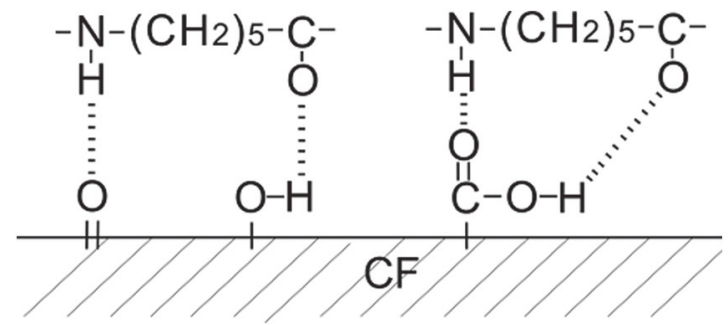

Fig. 11 Hydrogen bonding for carbon fiber and PA6.

Unsized-CF/PA6 より高い㵶維樹脂界面せん断強度を示 したと考えられる.

O-Unsized-CF/PA6 と比べて O-Unsized-CF/PA6(230)は, 低い繊維樹脂界面せん断強度を示した。試験片作製時 の温度が低い方が，繊維樹脂界面せん断強度は低くな 
った。一般的に，化学反応の速度は温度に依存する。 したがって, 試験片作製時の温度が低い方が低い繊維 樹脂界面せん断強度を示したことからも， O-Unsized-CF/PA6 は繊維樹脂間で化学反応が起こりや すくなったために，高い繊維樹脂界面せん断強度を示 したものと考えられる.

単繊維引抜き試験により求めた $\mathrm{CF} / \mathrm{PP}$ の繊維樹脂界 面せん断強度を Fig. 13 に示す. As-received-CF/PP とサ イジング剤を除去した Unsized-CF/PP, Unsized-CF/PP と O-Unsized-CF/PP の繊維樹脂界面せん断強度には有 意差は見られなかった．PP は極性を持たず化学結合を しにくいため, サイジング剤の除去や炭素繊維の酸化

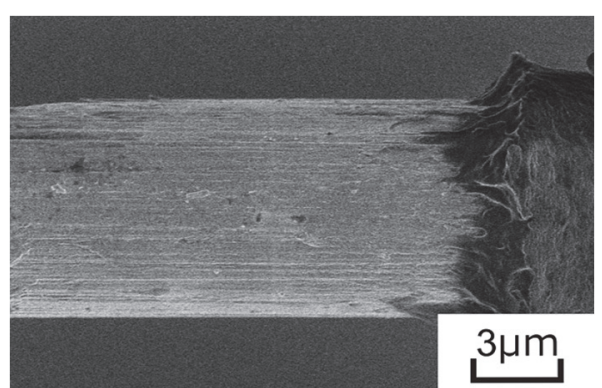

(a) Unsized-CF/PA6

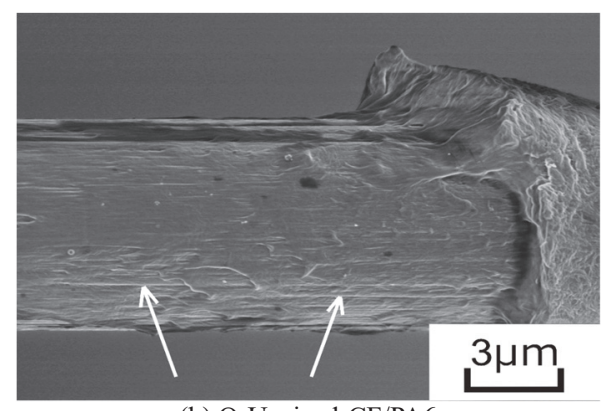

(b) O-Unsized-CF/PA6

Fig. 12 SEM images of pulled-out carbon fibers.
は，䋊維樹脂界面せん断強度に影響は及ぼさなかった と考えられる.

Unsized-CF/(PP+MAPP) は有意差はないものの Unsized-CF/PP よりも高い繊維樹脂界面せん断強度を示 し, O-Unsized-CF/(PP+MAPP)は O-Unsized-CF/PP より も高い繊維樹脂界面せん断強度を示した。これまで, $\mathrm{COOH}$ 基を持つ MAPP をPP に添加すると, Fig. 14 の ように, 樹脂と炭素繊維が水素結合や共有結合をし, 繊維樹脂界面せん断強度が向上する 20, 21) ことが報告さ れており, 本研究においても, 樹脂と炭素纎維が水素 結合や共有結合をし，高い繊維樹脂界面せん断強度を

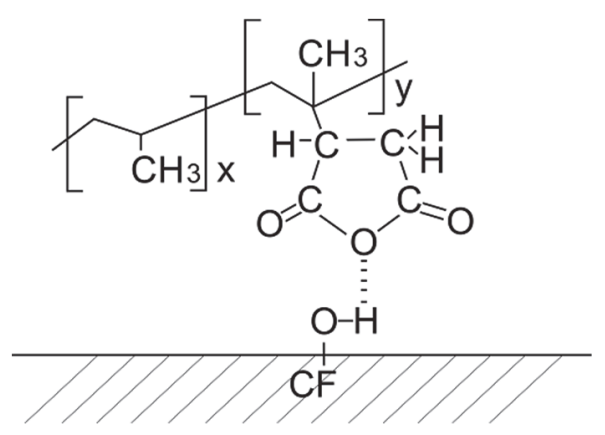

(a) Hydrogen bonding for carbon fiber and MAPP.

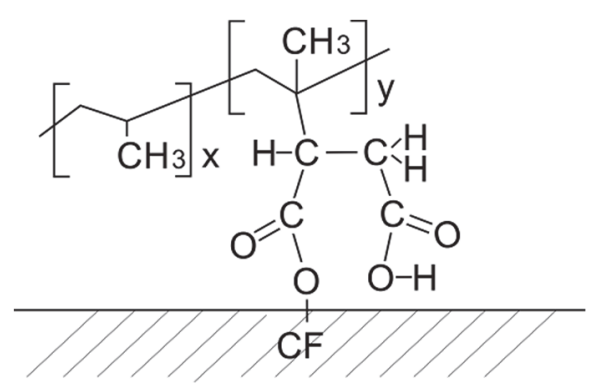

(b) Covalently bonding for carbon fiber and MAPP.

Fig. 14 Chemical bonding for carbon fiber and MAPP.

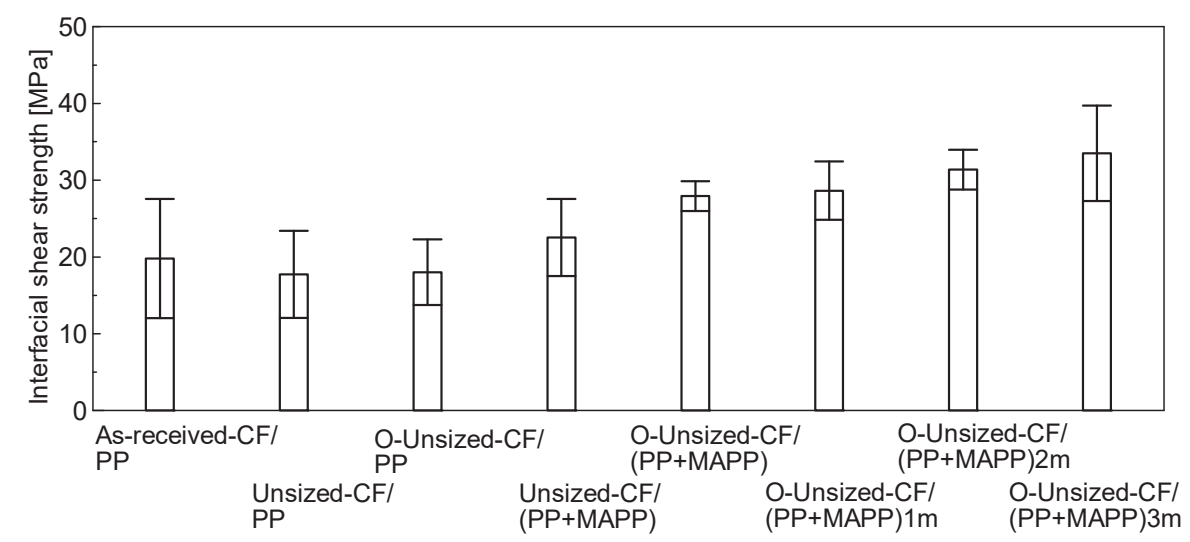

Fig. 13 Interfacial shear strength for $\mathrm{CF} / \mathrm{PP}$.

$$
(\mathrm{N}=5, \text { mean } \pm \text { S. D. })
$$


示したと考えられる。O-Unsized-CF/(PP+MAPP)は, Unsized-CF/(PP+MAPP)よりも高い緎維樹脂界面せん断 強度を示した，炭素繊維の酸化によって酸素含有官能 基が増加し，高い繊維樹脂界面せん断強度を示したと 考えられる.

O-Unsized-CF/(PP+MAPP)においては，有意差はない ものの試験片作成時の温度保持時間が長いほど高い纎 維樹脂界面せん断強度を示した. CF/PP の単繊維引抜き 試験後の繊維表面は, 繊維樹脂界面せん断強度が低い Unsized-CF/PP では繊維軸方向の筋状模様が繊維表面に 観察でき，䋊維樹脂界面で破壊が生じているのに対し て，繊維樹脂界面せん断強度が高くなるにつれて樹脂 が繊維表面に付着している部分も多くなり，纎維樹脂 界面と樹脂部の両者で破壊が生じる傾向にあった。 な お，これらの結果は，CF/PA6 の観察結果と同様の傾向 を示したため, FE-SEM 観察結果の掲載は省略する. 筆 者らは, 炭素繊維と MAPP 添加 PP を用いた単繊維引抜 き試験において，試験片作製時の樹脂溶融温度保持時 間が長い場合に繊維樹脂界面せん断強度が高くなる ${ }^{11)}$ ことを報告している，本研究においても，炭素繊維を 酸化させ酸素含有官能基を生成することで MAPP 添加 PP との化学結合がさらに増加し, 繊維樹脂界面せん断 強度が高くなったと考えられる。

炭素繊維強化樹脂複合材料において, 纎維と樹脂の 界面強度に寄与寸る結合として，化学的結合と物理的 結合が挙げられる 22). 3 ・1 節で述べたように, PP と MAPP 添加 PP が炭素繊維を締め付ける力に差は無いこ とから，O-Unsized-CF/(PP+MAPP)が Unsized-CF/PP よ

りも高い繊維樹脂界面せん断強度を示したのは，酸化 により炭素繊維に酸素含有官能基が生成され，樹脂と の化学結合が生じたことが主な原因であると考えられ る.

\section{4 結 言}

本研究では，空気酸化を施した炭素繊維と，PA6 ある いはPP と MAPP 添加 PP をマトリックスに用いて単繊維 引抜き試験を行い，繊維樹脂界面せん断強度に及ぼす炭 素繊維の空気酸化の影響を明らかにした。また，PA6につ いては温度が，MAPP 添加 PP については試験片作製時の 温度保持時間が繊維樹脂界面せん断強度に及ぼす影響も 明らかにした。以下に得られた知見を示す。

1. 炭素繊維のサイジング剤を除去することで, 炭素 繊維表面に酸素含有官能基が現れた. サイジング 剤除去炭素繊維と PA6 の綫維樹脂界面せん断強 度はサイジング剤を除去していないものよりも 高い值を示したが，PP では有意差は見られなか った.

2. 炭素繊維を酸化することで炭素繊維表面に酸素 含有官能基が生成され，炭素繊維と PA6 および MAPP 添加 PP の䋊維樹脂界面せん断強度は高い 值を示した。
3.PA6において, 高い温度で試験片を作製するほど， MAPP 添加 PP において, 試験片作成時の樹脂へ の繊維埋め込み時間が長くなるほど, 高い繊維樹 脂界面せん断強度を示した。

4. PA6およびMAPP 添加PP において炭素繊維の酸 化により高い纎維樹脂界面せん断強度を示した のは酸化により炭素繊維に生成された官能基に よるものと考えられる.

\section{参 考 文 献}

1) Y. Nakanishi and N. Ikuta, "Interphase of FRP and its chemical control", Journal of the Society of Materials Science, Japan, Vol.45, No.12, pp.1307-1315 (1996).

2) J. Koyanagi, H. Hatta, M. Kotani and H. Kawada, "A comprehensive model for determining tensile strengths of various unidirectional composites", Journal of Composite Materials, Vol.43, No.18, pp.1901-1914 (2009).

3) K. Terada, "Carbon fiber reinforced thermo plastics-currently, applications and forecast-", Journal of the Japan Society for Precision Engineering, Vol.81, No.6, pp.485-488 (2015).

4) M. Yamane, "Netsukasosei CFRP gijutsushuu", Science and Technology, pp.3-7 (2015).

5) K. Tanaka, A. Hirata and T. Katayama, "Continuous fiber reinforced thermoplastics molding by melted thermoplastic-resin transfer molding process", Journal of the Society of Materials Science, Japan, Vol.68, No.8, pp.628-635 (2019).

6) K. Tanaka, M. Kawabe and T. Katayama, "Evaluation of mechanical properties of press and injection hybrid molded products using CNT grafted plain woven carbon fiber fabric at rib roots", Journal of the Society of Materials Science, Japan, Vol.68, No.8, pp.636-642 (2019).

7) K. Tanaka, T. Takei and T. Katayama, "Bending property of multi-material hat shaped member of CFRTP and aluminum alloy", Journal of the Society of Materials Science, Japan, Vol.68, No.9, pp.704-711 (2019).

8) Y. Arao, S. Yumitori, H. Suzuki, T. Tanaka, K. Tanaka and T. Katayama, "Mechanical properties of injection-molded carbon fiber/polypropylene composites hybridized with nanofillers", Composites Part A: Applied Science and Manufacturing, Vol.55, pp.19-26 (2013).

9) M. G. Li, X. Wen, J. Liu and T. Tang, "Synergetic effect of epoxy resin and maleic anhydrive grafted polypropylene on improving mechanical properties of polypropylene/short carbon fiber composites", Composites Part A: Applied Science and Manufacturing, Vol.67, pp.212-220 (2013).

10) N. G. Karsli, A. Aytac, "Effects of maleated polypropylene on the morphology, thermal and mechanical properties of short carbon fiber reinforced polypropylene composites", Materials and Design, Vol.32, pp.4069-4073 (2011). 
11) K. Tanaka, K. Ohno and T. Katayama, "Effects of PP modification and processing time on fiber/matrix interfacial strength for carbon fiber reinforced polypropylene", WIT Transactions on the Built Environment, Vol.166, pp.329-334 (2016).

12) H. Oda, "Characteristics of interface on porous carbon materials and its applied technology", Tanso, No.235, pp.296-306 (2008).

13) A. Fukunaga, S. Ueda and M. Nagumo, "Air-oxidation and anodization of pitch-based carbon fibers”, Carbon, Vol.37, No.7, pp.1081-1085 (1999).

14) H. Oguma, D. Sakamoto, M. Harada, M. Sekine, N. Hirayama and G. Ben, "Increase of strength for CFRTP fabricated with carbon fiber fabrics and polyamide6 resin by ozone oxidation treatment", Japan Society for Composite Materials, Vol.43, No.1, pp.25-32 (2017).

15) J. Li, "Interfacial features of polyamide6 composites filled with oxidation modified carbon fibers", Journal of Mechanical Engineering and Science, Vol.223, pp.2135-2141 (2009).

16) K. Tanaka, K. Yamada, Y. Hinoue and T. Katayama, "Influence of unsizing and carbon nanotube grafting of carbon fibre on fibre matrix interfacial shear strength of carbon fibre and polyamide 6", Key Engineering Materials, Vol.827, pp.178-183 (2020).

17) K. Tanaka, N. Hosoo and T. Katayama, "Effects of temperature on the fiber matrix interfacial properties of carbon fiber reinforced highly heat resistant polyamide resin", Journal of the Society of Materials Science, Japan, Vol.66, No.10, pp.746-751 (2017).

18) S. J. Park and B. J. Kim, "Roles of acidic functional groups of carbon fiber surfaces in enhancing interfacial adhesion behavior", Materials Science and Engineering A, Vol.408, No.1, pp.269-273 (2005).

19) A. V. Sesha Sainath, T. Inoue, K. Yonetake and K. Koyama, "Thermal behavior of poly (acryloyloxybenzoic acid)/nylon 6 blends", Polymer, Vol.42, pp.9859-9862 (2001).

20) J. S. Kim and D. H. Kim, "Compatibilizing effects of maleic anhydride-grafted-polypropylene (PP) on long carbon fiber-reinforced PP composites”, Journal of Thermoplastic Composite Materials, Vol.28, No.11, pp.1599-1611 (2014).

21) H. I. Kim, W. Han, W. K. Choi, S. J. Park, K. H. An and B. J. Kim, "Effects of maleic anhydride content on mechanical properties of carbon fibers-reinforced maleic anhydride-grafted-polypropylene matrix composites", Carbon Letters, Vol.20, pp.39-46 (2016).

22) M. Nakatani and F. Nakao, "Effect of fiber/matrix interphase on the properties of CFRP", Sen'i Gakkaishi, Vol.44, No.2, pp.61-66 (1988). 